\title{
THE ZEMSKY SOBOR OF 1613: ELECTIONS WITHOUT CHOICE OR CHOICE WITHOUT ELECTIONS?
}

\author{
Dmitry V. Liseitsev \\ Institute of Russian history, RAS, Moscow, Russian Federation
}

\begin{abstract}
Introduction. There is a significant amount of research devoted to the Zemsky Sobor of 1613, but even nowadays historians cannot agree on this event. There is a dominating concept in historiography whose supporters consider the election to the throne of Mikhail Romanov as the result of the national consensus and unity and also regard this as the end of the Time of Troubles. Meanwhile, a great number of sources indicate the decisive role of Cossacks in the enthronement process of the new dynasty founder. Possessing a numerical superiority over the supporters of the Zemsky Sobor, which did not act in full force, Cossacks achieved the proclamation of Mikhail Romanov as a Tsar. Methods and materials. Solving this contradiction in the conclusions of researchers is possible only with the widest involvement of historical sources. First of all, the documents of the last weeks and days of "mezhdutsarstvie" should be analyzed. The attempts to follow ideologically conditioned concepts cannot bring satisfactory results in the solution of scientific problems. Analysis. Document analysis of the late 1612 and the early1613 leads to the conclusion that after the liberation of Moscow, the real power in the capital was in the hands of "duumvirate" - the leaders of the militia of Pr. D.T. Trubetskoy and Pr. D.M. Pozharsky. They did not lose their influence even when many orders were officially proclaimed on behalf of the Zemsky Sobor. At the same time, Pr. Trubetskoy seriously planned to take the throne with the help of Cossacks. The unexpected intervention of Cossacks in the support of Mikhail Romanov broke Trubetskoy's plans. Nevertheless, the "duumvirs" tried to ignore the acclamation that took place on February 21, 1613 for several days. Results. Only under the pressure of the armed Cossack mass, the government had to swear allegiance to Mikhail Romanov and begin notifying provinces on the election of a new sovereign. Despite this fact, the leaders of the people's militia retained the influence in the capital until the arrival of Tsar Mikhail to Moscow. Thus, preserved sources allow to significantly clarify the course of political events in Moscow in the first months of 1613.

Key words: The Time of Troubles, the Moscow State, the Zemsky Sobor of 1613, Mikhail Fedorovich Romanov, Cossacks, government of the "Council of All the Earth".

Citation. Liseitsev D.V. The Zemsky Sobor of 1613: Elections Without Choice or Choice Without Elections? Vestnik Volgogradskogo gosudarstvennogo universiteta. Seriya 4, Istoriya. Regionovedenie. Mezhdunarodnye otnosheniya [Science Journal of Volgograd State University. History. Area Studies. International Relations], 2019, vol. 24, no. 2, pp. 137-146. (in Russian). DOI: https://doi.org/10.15688/jvolsu4.2019.2.12
\end{abstract}

\section{ЗЕМСКИЙ СОБОР 1613 г.: ВЫБОРЫ БЕЗ ВЫБОРА ИЛИ ВЫБОР БЕЗ ВЫБОРОВ?}

\section{Дмитрий Владимирович Лисейцев}

Институт российской истории РАН, г. Москва, Российская Федерация

Аннотация. Введение. Земскому собору 1613 г. посвящено значительное количество исследований, но и сегодня историки далеки от выработки общего взгляда на это событие. В историографии преобладает концепция, сторонники которой считают избрание на престол Михаила Романова результатом всенародного согласия и единения и видят в нем едва ли не конец Смутного времени. Между тем значительное количество 
источников указывает на решающую роль казачества в возведении на престол основателя новой царской династии. Обладая численным превосходством над сторонниками так и не собравшегося в полном составе Земского собора, казаки добились провозглашения царем Михаила Романова. Методы и материальл. Решить это противоречие в выводах исследователей можно лишь при условии максимально широкого привлечения исторических источников. В первую очередь должны анализироваться документы, созданные в последние недели и дни «междуцарствия». Попытки руководствоваться в решении научных проблем идеологически обусловленными концепциями удовлетворительных результатов принести не могут. Анализ. Анализ документов конца 1612 - начала 1613 г. позволяет сделать вывод о том, что после освобождения Москвы реальная власть в столице находилась в руках «дуумвирата» - предводителей Ополчений кн. Д.Т. Трубецкого и кн. Д.М. Пожарского. Они не утратили влияния и после того, как многие распоряжения официально стали исходить от имени Земского собора. При этом кн. Трубецкой всерьез рассчитывал при поддержке казачества занять престол. Неожиданное выступление казаков в поддержку кандидатуры Михаила Романова расстроило планы Трубецкого. Тем не менее «дуумвиры» на протяжении нескольких дней пытались игнорировать состоявшуюся 21 февраля 1613 г. аккламацию. Результаты. Лишь под давлением вооруженной казачьей массы правительству пришлось присягнуть Михаилу Федоровичу и начать оповещение провинций об избрании нового государя. Несмотря на это предводители народных Ополчений сохраняли влияние в столице вплоть до прибытия царя Михаила в Москву. Сохранившиеся источники, таким образом, позволяют существенно уточнить ход политических событий в Москве в первые месяцы 1613 года.

Ключевые слова: Смутное время, Московское государство, Земский собор 1613 г., Михаил Федорович Романов, казачество, правительство «Совета всея земли».

Цитирование. Лисейцев Д. В. Земский собор 1613 г.: выборы без выбора или выбор без выборов? // Вестник Волгоградского государственного университета. Серия 4, История. Регионоведение. Международные отношения. - 2019. - Т. 24, № 2. - C. 137-146. - DOI: https://doi.org/10.15688/jvolsu4.2019.2.12

Введение. 21 февраля 1613 г. на престол избрали Михаила Федоровича Романова. Это событие подверглось идеологической проработке сначала в публицистических сочинениях современников, а затем и в трудах историков. Отголоски мифологизированного взгляда на акт провозглашения Михаила Романова царем слышны и сегодня - ученые и публицисты, над которыми уже не довлеет подконтрольная потомкам избранного в 1613 г. государя цензура, продолжают утверждать, что царским избранием 21 февраля в Смутном времени была поставлена точка [4, с. 424; 19 , с. $3 ; 16$, с. 440$]$.

Методы, материалы. В силу ряда обстоятельств Земский собор 1613 г. оказался на острие внимания ученых и публицистов. Наряду с появлением профессиональных исследований истории этого события, ученое сообщество сталкивается с очерками политизированными, написанными иногда с позиций «наивного монархизма». П.Б. Уваров и С.Г. Дмитрина, например, обвиняют современную науку в зависимости от «историософии советского периода» и «идей классиков дореволюционной историографии». В вину исследователям ставится «переоценка идеи социального консенсуса», «абсолютный анахронизм» и «нарушения принципа историзма». Вследствие этого «не всегда, теоретико-методологические основания, выбранные нашими современниками, способствуют компетентным экспертным выводам в данной области» (здесь и далее сохранена пунктуация и орфография авторов. - Д. Л.). В качестве панацеи в излечении «инфицированной постулированием произвольных допущений» исторической науки от ее «архаичного, теоретико-методологического состояния» предложено использовать - «дедуктивную археологию», которая «заключается в предельном допущении о природе исторической реальности». Иначе говоря, с вредными для науки «произвольными допущениями» предлагается бороться с помощью некоего полезного «предельного допущения». В чем суть последнего в контексте выбранной авторами темы - остается догадываться. Вероятно, в том, что «власть народа, в понимании средневекового человека, нарушала иерархию сакрального, поскольку только монарх, помазанник Бога на земле, мог управлять государством», а «восстановление сакральной вертикали было главной исторической заслугой дворян, купцов, духовенства и крестьян» [33, с. 36-40]. Эта схема сама по себе не лучше и не хуже прочих. Проблема состоит в том, что в фундаменте подобных построений отсутствует даже попытка опереться на что-нибудь, кроме собственных представлений 
о сущности исторических событий. Во всяком случае, обращения к столь низменной материи как исторические источники «дедуктивная археология» с ее «предельным допущением», вероятно, не предусматривает. Рискуя показаться неоригинальным, напомню, что любое историческое исследование должно опираться на источники. Лишь их максимально широкое привлечение, сопоставление и критика дают возможность приблизиться к пониманию сути событий прошлого.

Анализ. В основе мифологизированного взгляда на события начала 1613 г. лежит концепция, берущая начало в сочинениях публицистов первых лет царствования Михаила Романова. Общий ее смысл в том, что Земский собор 1613 г. не имел возможности принять иное решение кроме провозглашения царем Михаила Федоровича, поскольку такой оборот событий был предопределен Богом. Согласно этому взгляду, иные кандидаты на соборе 1613 г. отсутствовали (иначе говоря, это были «выборы без выбора»). Формирование этой концепции началось в конце февраля 1613 г. с составления первых грамот с извещением о царском избрании. В них изложена схема, согласно которой Земский собор с начала работы отверг кандидатуры иноземных претендентов, равно как и сына Марины Мнишек («Ворёнка»). Единогласное одобрение вызвала персона Михаила Федоровича [15, c. $188-192]$.

Оформленная позднее «Утвержденная грамота» об избрании на престол Михаила Романова выдержана в тех же тонах: «И по многие дни на соборе... всякие люди не обинуяся говорили и единомышленной совет... объявливали, что быти... на всех великих преславных Росийских государствах государем... Михаилу Федоровичю Романову-Юрьеву» [16, c. 500-501]. Грамоте вторили публицисты Авраамий Палицын, Арсений Елассонский и анонимный автор «Нового летописца», превратившие упомянутый в ней «глас народа» во «всенародный вопль»: «и еще прежде вопрошениа во всем народе, яко от единех уст вси возопишя: “Михаил Феодорович да будет царь”» [11, с. 200; 28, с. 232-233; 22, с. 129]. Многие историки продолжили пропаганду этой точки зрения, попытавшись, разве что, заменить «Божью волю» более рациональными аргументами - родством Михаила Федоровича с угасшей династией, особым уважением казаков-тушинцев к его отцу - митрополиту Филарету, усталостью общества от потрясений Смуты и даже слабостью юного государя - не столько «достойнейшего», сколько «удобнейшего».

Свидетельств тому, что описанная в официальных источниках картина не вполне соответствовала действительности, историография накопила предостаточно. Поддержкой в среде боярства пользовалась кандидатура шведского принца Карла-Филиппа. Русские купцы, приехавшие в начале февраля 1613 г. в Новгород, сообщили, что бояре отвергли предложенного казаками Михаила Романова, а сами склонялись к провозглашению государем шведского королевича [6, с. 21-23]. Выехавший в составе посольства в Данию переводчик Дмитрий Миколаев утверждал, что «на Москве государя... выбирали чорные люди, а лутчие... хотели свейского королевича» [26, л. 176, 179].

Пользовалась поддержкой и фигура польского королевича Владислава. Свидетельством тому является не только широко известная история с пленением сына боярского Ивана Философова, заявившего на допросе, что «на Москве у бояр... и у лутших людей хотение есть, чтоб просити на господарство... великого господаря королевича Владислава Жигимонтовича, а имянно де о том говорити не смеют, боясь казаков» [24, с. 344]. Кандидатура польского королевича пользовалась у бояр популярностью и после избрания на престол Михаила Федоровича. Летом 1613 г. шведы получили информацию о том, что бояре кн. Д.Т. Трубецкой и Ф.И. Шереметев отправили в Речь Посполитую гонцов, прося короля Сигизмунда III следовать с войском к Москве для возведения на престол Владислава. Гонцов схватили, и выяснилось, что в сговоре с Трубецким и Шереметевым находился даже дядя царя Михаила боярин И.Н. Романов [6, с. 23]. Достоверность этой информации косвенно подтверждает челобитная плененного в июне 1613 г. польского ротмистра Яна Синявского: сопровождавшие его в Москву казаки «научили... порутчика Ерошку на... бояр на князя Федора Ивановича Мстисловского с товарыщи и на меня; ...заводя такую 
статью, хотели бояр побить. А я, холоп ваш, ...был на пытке и живот свой мучил и кровь неповинную пролил, очищаючи бояр и себя» [8, л. 550].

Имелись сторонники и у «Ворёнка». Иван Философов свидетельствовал в польском плену, что казаки намеревались «обрать кого из русских бояр, а примеривают Филаретова сына или воровского Колужского». В начале 1613 г. многие казаки по-прежнему стояли за сына Марины Мнишек: по показаниям шведского очевидца, едва ли не половина находившихся под Москвой казаков, не добившись поддержки на Соборе, удалилась к атаману Заруцкому [20, с. 507]. Были претенденты и среди представителей русских боярских родов - таковых насчитывается до десяти человек [25, с. 90-94].

Какую роль в избрании Михаила Романова сыграл Земский собор? В историографии утвердилась точка зрения, что этот орган власти несколько месяцев управлял страной как «временное правительство» [32, с. 187]. Сохранившиеся документы не позволяют принять эту точку зрения. Наиболее ранняя грамота о присылке выборных для участия в Соборе (в Соль Вычегодскую от 11 ноября 1612 г.) написана от лица князей Д. Трубецкого и Д. Пожарского с товарищи, а не от собора или «совета всея земли» [18, с. 314]. Обе грамоты на Белоозеро (от 19 ноября и 27 декабря 1612 г.) направлены от «дуумвирата» Трубецкого и Пожарского [21, с. 99, 107]. Грамота на Двину от 31 декабря 1612 г. написана от их же имени, хотя в ней и констатировали прибытие в Москву представителей многих городов [15, с. 187]. По приговорам Трубецкого и Пожарского были даны грамоты в Шую (2 декабря 1612 г.) [21, с. 103], Новодевичий монастырь (18 декабря) [29, с. 609], Арзамас (4 января, 5 и 15 февраля 1613 г.) [5, c. $465,466,468,471,474,478]$, Соловский уезд (9 февраля) [3, с. 348-349]. 19-20 февраля Трубецкой и Пожарский отдали распоряжения о придачах четвертного жалования служилым людям без апелляций к авторитету Собора [9, л. 83 об.; 21, с. 128$]$.

Закономерен вопрос - действительно ли в конце 1612 - начале 1613 г. власть в стране принадлежала Земскому собору или «совету всея земли»? Общаясь с городами и уездами, правящий «тандем» не считал необходимым апеллировать к авторитету Собора. Первый документ, составленный от имени Собора январская жалованная грамота кн. Д.Т. Трубецкому на владение волостью Вага. Здесь впервые перечисляются представители разных чинов Московского государства: «митрополиты, и архиепископы, и епископы, и архимандриты, и игумены, и весь Освященный собор, и цари, и царевичи разных земель, которые служат в Московском государстве, и бояре, и околничие, и столники, и стряпчие, и дворяне, и приказные люди, и дворяне из городов, и дети боярские, и всякие служилые, и гости, и торговые и всяких чинов люди Московского государства». В дальнейшем этот перечень чинов воспроизводился в грамотах, составленных от имени Собора [12, с. 232]. В жалованной грамоте Трубецкому усматривают едва ли не компенсацию за отклонение его кандидатуры на царский трон. Однако грамота превозносит боярина, приписывая ему основную заслугу в освобождении Москвы. Накануне царского избрания это могло стать обоснованием его притязаний на трон. Исключительность документа (оформление от имени Собора) понятна - пожалование Трубецким себя самого выглядело бы странно.

Подписи на этом документе позволяют очертить круг городов, приславших представителей в Москву уже в январе: Ярославль, Ростов, Рязань, Калязин, Торжок и Коломна. Находились в Москве также выборные от Тулы, Владимира, Кадома, Новосиля и Черни $[31$, с. 96, 97, 101]. Вряд ли они были полномочны действовать от имени «всей земли». Поэтому из Москвы продолжали идти грамоты с требованием прислать выборных людей [17, с. 214-215]. Как свидетельствуют документы, Собор в полном составе так и не собрался, что не помешало грамотами от 25 февраля 1613 г. известить страну о «соборном» избрании государя.

Стройности картины «всенародного избрания» Михаила Федоровича, не имевшего себе альтернативы, противостоят не только приведенные факты. Около 30 лет назад в научный оборот введена «Повесть о Земском соборе 1613 года», недвусмысленно показывающая Михаила Романова казачьим ставленником. Согласно этому источнику, бояре пред- 
полагали выбрать царя из собственной среды, игнорируя мнение казаков. Уставшие ждать царского избрания казаки добились приглашения на Собор, где ими и был провозглашен царем Михаил Романов [25, с. 90-94]. «Повесть», таким образом, говорит не о выборах как таковых, а скорее об аккламации. Особую роль казаков в деле избрания царя Михаила отмечает и «Бельский летописец», констатировавший также единодушие и непродолжительность выборов («и почали выбирати царя, и немного о сем советовали, и единеми усты глаголаху, что быти царю Михаилу Федоровичю Романову, и паче всех казаки») [23, с. 219].

Отголоски борьбы, развернувшейся в Москве в феврале 1613 г., обнаруживаются в грамоте, отправленной около 25 февраля в Казань. В ней сообщается, что «всех людей Московского государства» пришлось «упрашивать» о сроке избрания - 21 февраля. В грамоте в духе риторики прочих правительственных документов утверждалось, будто избрание Михаила Федоровича произошло единодушно. Осуществление выбора без казанской делегации оправдывали требованиями ратных людей (в том числе казаков) - те «приходили на нас с великим шумом и ставили нам о государском обиранье в нерадение». И, наконец, любопытная деталь, не встречающаяся в других посланиях об избрании на престол Михаила Романова: 24 февраля от авторов грамоты потребовали немедленно послать за государем в Кострому, после чего и последовала присяга ему [17, с. 216-218].

О том, что не все прошло так гладко, как изображали официальные документы, свидетельствуют и другие источники. По сведениям шведов, казаки вообще не были сторонниками выборов как таковых, предлагая бросить жребий между несколькими кандидатами (в числе которых назван и М.Ф. Романов) [6, c. 30]. Не встретив поддержки бояр, часть казаков отъехали к атаману Заруцкому; уехали из Москвы и торопецкие дворяне [13, с. 141, 236]. Глава оккупационных властей Новгорода генерал Делагарди в донесении от 13 апреля сообщал о провозглашении казаками Михаила царем «против воли бояр». Более того, казаки «своих военачальников князя Дмитрия Тимофеевича Трубецкого и князя Дмитрия Михайловича Пожарского в их до- мах осадили и принудили их согласиться на свое избрание великого князя» [14, с. 73-74]. Русские пленные летом 1614 г. сообщили шведам, что «казаки и чернь сбежались и с большим шумом ворвались в Кремль к боярам и думцам, напустились на них с сильными ругательствами», требуя возведения на престол Михаила Романова и настояв на немедленной присяге ему [6, с. 30-31]. Этот момент достоин особого внимания: страна приносила присягу человеку, не давшему официального согласия принять царский венец. Известия о целовании креста Михаилу стали поступать в Москву раньше, чем посланная к нему делегация разыскала его в Костроме. Спешка с присягой может быть объяснена лишь давлением со стороны казачьей массы.

Наиболее ранние грамоты, извещавшие страну об избрании государя, датированы 25 февраля 1613 года. Если придерживаться версии о единогласном соборном избрании на престол Михаила Романова 21 февраля, то возникает вопрос: почему на протяжении четырех дней столичные власти умалчивали об этом событии? От этого промежутка времени известно лишь послание в Галич от 22 февраля. Документ составлен от имени Трубецкого и Пожарского, и в нем нет ни слова о том, что в Москве накануне избран государь [1, с. 407-408; 20, с. 266-267]. 25 февраля первые грамоты об избрании государя были посланы в Казань, Владимир, на Двину и в Пошехонье [30, с. 11]. Две последние удостоверены рукоприкладствами первых чинов Освященного собора; двинскую грамоту подписали также восемь бояр и окольничих, грамоту в Пошехонье - четыре. Обе грамоты скрепил подписью кн. Пожарский, а подписи кн. Трубецкого на них нет. Грамоту на Двину подписали также выборные от Каширы, Торжка, Рязани, Одоева, Вологды, Устюжны Железопольской, Торопца и Мценска, в Пошехонье - Мценска, Погорелого городища и Боровска $[27$, с. $181-183 ; 15$, с. $188-192 ; 18$, c. 407-408]. Круг уездов, представленных на Соборе, оставался узким.

С 27 февраля Земский собор стал апеллировать к имени новоизбранного государя: из Разрядного приказа во Владимирскую четверть направили распоряжение о рассылке грамот с запретом давать жалование без раз- 


\section{ИСТОРИЯ СМУТНОГО ВРЕМЕНИ}

решения «всего Собору и без боярского приговору»; собранные деньги указали присылать в Москву к государю Михаилу Федоровичу. Даже в самой столице деньги выдавать разрешалось лишь с позволения Собора [21, с. 128 , 129], что заслуживает особого внимания. В тот же день сменился руководитель Печатного приказа, остававшегося в те дни единственным источником, из которого правительство получало хоть и небольшие, но «живые» деньги. Особенно интересно, что предыдущий руководитель приказа - дьяк Меркурий Любученинов, служивший ранее с кн. Трубецким в I Ополчении, заступил на свой пост незадолго до того - 19 февраля [10, с. 11]. Похоже, проигравшего в схватке за власть боярина, потратившего немало денег на агитацию в свою пользу и не сумевшего пережить поражения с достоинством [25, с. 94], стали оттеснять от финансовых рычагов.

К первым числам марта 1613 г. грамоты из Москвы стали оформлять от лица Михаила Федоровича, а отписки костромского посольства в Москву адресовались Освященному собору и боярам [7, стб. 1049]. Это не означало, однако, что «дуумвират» лишился власти. Составленная 2 марта грамота в сибирскую Мангазею написана от лица «бояр и воевод», причем в документе имя царя Михаила даже не упоминается $[34$, с. $55 ; 2$, с. 230]. Очень любопытно выглядит формулировка мартовской памяти в Шую: «по государеву цареву и великого князя Михаила Федоровича всеа Русии указу и по приговору и по наказу боярина и воеводы князя Дмитрея Тимофеевича Трубецкого да столника и воеводы князя Дмитрея Михайловича Пожарского». Даже в черновике послания к царю Михаилу от конца марта обнаруживается вычерненный фрагмент - «мы, холопи твои, Дмитрей Трубецкой да Дмитрей Пожарской» [7, стб. 1083; 18, с. 320]. Полностью отстранить «тандем» от власти ни импровизированный Собор, ни Боярская дума вплоть до прибытия в Москву Михаила Федоровича не смогли: они по-прежнему пользовались поддержкой участников Ополчений. И «дуумвиры» не упустили возможности напомнить царю об этом, отправив накануне его прибытия в столицу челобитную о разрешении выехать к нему навстречу во главе своих пол- ков: «и ныне... приходят к нам стольники и стряпчие, и дворяне московские, и жильцы, и приказные люди, и из городов дворяне и дети боярские, которые с нами... были под Москвою, и бьют челом..., чтоб им видеть твои царские очи» [7, стб. 1207].

Результаты. Картина событий реконструируется следующим образом. Попытка собрать Земский собор для выбора царя успехом не увенчалась: многие регионы так и не успели к концу февраля 1613 г. прислать своих представителей. Казаков в число участников Собора не включили, предполагая направить их против атамана Заруцкого. Около 7 февраля казаки, которым под предлогом отсутствия законного государя задерживали выплату жалования, выдвинули требование ускорить процесс выборов, и правительству пришлось «упрашивать» их о двухнедельной отсрочке. 21 февраля казаки потребовали провозглашения царем Михаила Романова и вынудили находившихся в Москве выборных людей согласиться на это. Правящий «дуумвират» пытался продолжить управление страной, но 24 февраля казаки настояли на присяге царю. Лишь после этого 25 февраля началась рассылка грамот о состоявшемся в столице «избрании», причем правительству пришлось выдавать случившееся за акт добровольного и всенародного избрания. И если кн. Пожарский согласился поддержать эту «игру» почти сразу, то кн. Трубецкой признать свершившийся факт оказался не готов: не случайно на грамотах об избрании Михаила Романова царем его подпись отсутствует. Учет совокупности сохранившихся документов позволяет констатировать - широкий выбор кандидатов на царский престол в 1613 г. имелся, а потому говорить о «выборах без выбора» не приходится. Однако выборы как таковые не состоялись - представители большинства городов в Москву не приехали, и вопрос о престоле решили казаки. Иначе говоря, это был «выбор без выборов».

\section{СПИСОК ЛИТЕРАТУРЫ}

1. Акты исторические, собранные и изданные Археографическою комиссиею : [в 5-ти т. с доп. и указ.]. Т. 2 : 1598-1613. - СПб. : Тип. ІІ отд-ния Собственной Его Императорского Величества канцелярии, 1841. - IV + 438 + $31 \mathrm{c}$. 
2. Акты служилых землевладельцев XV - начала XVII в. : сб. док. T. III / сост. А. В. Антонов. М. : Древлехранилище, 2002. -680 с.

3. Акты служилых землевладельцев XV-начала XVII в. : сб. док. T. IV / сост. А. В. Антонов. М. : Древлехранилище, 2008. -632 с.

4. Антонов, Д. А. Смута в культуре средневековой Руси: Эволюция древнерусских мифологем в книжности начала XVII века / Д. А. Антонов. М. : Изд-во РГГУ, 2009. - 424 с.

5. Арзамасские поместные акты (15781618 гг.) / сост. С. Б. Веселовский // Смутное время Московского государства (1604-1613 гг.) : материалы, изданные Императорским обществом истории и древностей российских при Московском университете. Вып. 4. - М. : Тип. Г. Лисснера и Д. Совко, 1915. $-\mathrm{XVI}+736 \mathrm{c}$.

6. Арсеньевские шведские бумаги // Сборник Новгородского общества любителей древности. Вып. V. - Новгород : Губернская типография, 1911. - XI + $120+$ II c.

7. Дворцовые разряды, по высочайшему повелению изданные II-м отделением Собственной Его Императорского Величества канцелярии 1612 по 1628 г. Т. І. - СПб. : Тип. II отд-ния Собственной Его Императорского Величества канцелярии, 1850. - XXXVI с. + 1224 стб. + ХІІ стб.

8. Документы, касающиеся иноземцев, главным образом поляков, литовцев и немцев, бежавших в Москву из войска королевича Владислава (дачи жалования за выход и крещение) // Российский государственный архив древних актов (РГАДА).Ф. 210. - Оп. 13. - Д. 7. - 601 л.

9. Документы о служилых людях, главным образом - жильцах (о назначениях, переводах, льготах, отпусках, отставке, о «приездах» и смотрах, о нетчиках, отписке у них имений и заключении в тюрьму, о пожаловании за службы поместными и денежными окладами, о справе придач) // РГАДА. Ф. 210. - Оп. 9. - Д. 6. - Ч. 2. - 430 л.

10. Документы Печатного приказа (16131615 гг.) / сост. С. Б. Веселовский. - М. : Наука, 1994. $-479 \mathrm{c}$.

11. Елассонский, А. Мемуары из русской истории / А. Елассонский // Хроники Смутного времени. - М. : Фонд Сергея Дубова, 1998. - С. 163-210.

12. Забелин, И. Е. Минин и Пожарский. Прямые и кривые в Смутное время / И. Е. Забелин. СПб. : Русская симфония, 2005. - 272 с.

13. Замятин, Г. А. Из истории борьбы Швеции и Польши за московский престол в начале XVII века. Падение кандидатуры Карла Филиппа и воцарение Михаила Федоровича // Россия и Швеция в начале XVII века. Очерки политической и военной истории / Г. А. Замятин. - СПб. : Европейский дом, 2008. - 494 с.
14. Замятин, Г. А. К истории Земского собора 1613 года / Г. А. Замятин // Труды Воронежского государственного университета. - 1926. - Т. III. - С. 71-74.

15. Зимин, А. А. Акты Земского собора $1612-$ 1613 гг. / А. А. Зимин // Записки Отдела рукописей. Вып. 19. - М. : Государственная библиотека СССР им. В. И. Ленина, 1957. - С. 186-194.

16. Козляков, В. Н. Смута в России. XVII век / В. Н. Козляков. - М. : Омега, 2007. - 528 с.

17. Корецкий, В. И. Документы о национально-освободительной борьбе в России в 1612-1613 гг. / В. И. Корецкий, М. П. Лукичев, А. Л. Станиславский // Лукичев, М. П. Боярские книги XVII века: Труды по истории и источниковедению / М. П. Лукичев. - М. : Древлехранилище, 2004. - С. 198-234.

18. Любомиров, П. Г. Очерк истории Нижегородского ополчения 1611-1612 гг. / П. Г. Любомиров // Подвиг Нижегородского ополчения. Т. 2. Н. Новгород : Книги, 2011. - С. 11-452.

19. Морозова, Л. Е. Россия на пути из Смуты. Избрание на царство Михаила Федоровича / Л. Е. Морозова. - М. : Наука, 2005. - 467 с.

20. Нижегородская ученая архивная комиссия. Действия Нижегородской губернской ученой архивной комиссии : сб. ст., сообщений, описей дел и документов : Т. [1]-18. - Н. Новгород : Типолитография акционерного общества «Самообразование», 1912. - Т. XI : Памятники истории Нижегородского движения в эпоху Смуты и земского ополчения 1611-1612 гг. - XXXIII + 570 c.

21. Новые акты Смутного времени. Акты подмосковных ополчений и Земского собора 16111613 гг. / сост. С. Б. Веселовский // Чтения в Императорском обществе истории и древностей российских при Московском университете. Кн. 4. - М. : Синодальная типография, 1911. - XIV + 228 с.

22. Новый летописец // Полное собрание русских летописей (ПСРЛ). - Т. XIV, ч. 1. - СПб. : Тип. М.А. Александрова, 1910. - С. 23-154.

23. Пискаревский летописец // ПСРЛ. Т. 34. М. : Наука, 1978. - С. 31-220.

24. Платонов, С. Ф. Московское правительство при первых Романовых // Собрание сочинений : в 6 т. Т. 3 / С. Ф. Платонов.- М. : Наука, 2012.С. 254-302.

25. Повесть о Земском соборе 1613 года / Б. Н. Морозов, А. Л. Станиславский // Вопросы истории. - 1985. - № 5. - С. 90-94.

26. Приезд и отпуск из Москвы датского посланника Ивервинта, переводчика Мучки и дворянина Мартына Голфенда с поздравлением царя Михаила Феодоровича о вступлении его на российский престол и с предложением об окончании споров издавна между обоими государствами происходивших касательно Лапландии // РГАДА. - Ф. 53. Оп. 1. - Д. 1. (1614 г.). -342 л. 
27. Разрядная книга 1598-1638 гг. / сост. В. И. Буганов, Л. Ф. Кузьмина. - М. : Ин-т истории СССР АН CCCP, 1974. - 398 c.

28. Сказание Авраамия Палицына. - М. ; Л. : Изд-во АН СССР, 1955. - 348 с.

29. Собрание государственных грамот и договоров, хранящихся в Государственной коллегии иностранных дел. Ч. ІІ. - М. : Тип. Селивановского, 1819. $-3+\mathrm{VIII}+19+612 \mathrm{c}$.

30. Собрание государственных грамот и договоров, хранящихся в Государственной коллегии иностранных дел. Ч. ІІІ. - М. : Тип. Селивановского, 1822. - XII $+540 \mathrm{c}$.

31. Сухотин, Л. М. Первые месяцы царствования Михаила Федоровича (Столбцы Печатного приказа) / Л. М. Сухотин. - М. : Синодальная типография, 1915. $-\mathrm{XXIV}+240 \mathrm{c}$.

32. Черепнин, Л. В. Земские соборы Русского государства XVI-XVII вв. / Л. В. Черепнин. - М. : Наука, 1978. - $418 \mathrm{c}$.

33. Уваров, П. Б. Современная отечественная историография об историческом значении избрания на царство Михаила Федоровича Романова / П. Б. Уваров, С. Г. Дмитрина // Вестник Южно-Уральского государственного университета. Серия «Социально-гуманитарные науки». - 2018. - Т. 18, № 2. - С. 36-40.

34. Эскин, Ю. М. Документы о Мангазее в Смутное время / Ю. М. Эскин // Новые материалы по истории Сибири досоветского периода. - Новосибирск : Наука. Сиб. отд-ние, 1986. - С. 44-54.

\section{REFERENCES}

1. Akty istoricheskie, sobrannye i izdannye Arkheograficheskoyu komissieyu: [v 5-ti t. s dop. $i$ ukaz.]. T. 2: 1598-1613 [Historical Acts Collected and Published by the Archaeological Commission. In 5 vols. Vol. 2: 1598-1613]. Saint Petersburg, Tipografiya II otdeleniya Sobstvennoy Ego Imperatorskogo Velichestva Kantselyarii, 1841. IV $+438+31$ p.

2. Antonov A.V., ed. Akty sluzhilykh zemlevladeltsev XV-nachala XVII v.: sb. dok. T. III [Acts of Serving Landowners of the $15^{\text {th }}$ - the Early $17^{\text {th }}$ c. Collection of Documents. Vol. 3]. Moscow, Drevlekhranilishche Publ., 2002. 680 p.

3. Antonov A.V., ed. Akty sluzhilykh zemlevladeltsev XV-nachala XVII v.: sb. dok. T. IV [Acts of Serving Landowners of the $15^{\text {th }}-$ the Early $17^{\text {th }}$ c. Collection of Documents. Vol. 4]. Moscow, Drevlekhranilishche Publ., 2008. 632 p.

4. Antonov D.A. Smuta v kulture srednevekovoy Rusi: Evolyutsiya drevnerusskikh mifologem v knizhnosti nachala XVII veka [The Time of Troubles in the Culture of Medieval Russia: the Evolution of Ancient Mythologems in the Book
Learning of the Early $17^{\text {th }}$ Century]. Moscow, Izd-vo RGGU, 2009. 424 p.

5. Veselovskiy S.B., ed. Arzamasskie pomestnye akty (1578-1618 gg.) [Arzamas Acts on Estates (1578-1618)]. Smutnoe vremya Moskovskogo gosudarstva (1604-1613 gg.): materialy, izdannye Imperatorskim obshchestvom istorii $i$ drevnostey rossiyskikh pri Moskovskom universitete. Vyp. 4 [The Time of Troubles of the Moscow State (16041613). Materials Published by the Imperial Society of History and Antiquities of Russia at Moscow University. Iss. 4]. Moscow, Tipografiya G. Lissnera i D. Sovko, 1915. XVI + 736 p.

6. Arsenyevskie shvedskie bumagi [Arsenyev Swedish Papers]. Sbornik Novgorodskogo obshchestva lyubiteley drevnosti. Vyp. V [The Collection of the Novgorod Society of Antiquities. Iss. V]. Novgorod, Gubernskaya tipografiya, 1911. XI + 120+ II p.

7. Dvortsovye razryady, po vysochayshemu poveleniyu izdannye II-m otdeleniem Sobstvennoy Ego Imperatorskogo Velichestva kantselyarii 1612 po 1628 g. T. I [Palace Charges by the Highest Order Issued by the II Department of His Imperial Majesty's Own Chancery Between 1612 and 1628. Vol. I]. Saint Petersburg, Tipografiya II otdeleniya Sobstvennoy Ego Imperatorskogo Velichestva Kantselyarii, 1850. XXXVI p. + 1224 col. + XII col.

8. Dokumenty, kasayushchiesya inozemtsev, glavnym obrazom polyakov, litovtsev i nemtsev, bezhavshikh v Moskvu iz voyska korolevicha Vladislava (dachi zhalovaniya za vykhod i kreshchenie) [Documents Relating to Foreigners, Mainly Poles, Lithuanians and Germans Who Fled to Moscow from the Army of Prince Vladislav (Giving Salaries for Disaffiliation and Baptism)]. Rossiyskiy gosudarstvennyy arkhiv drevnikh aktov [Russian State Archive of Ancient Acts], F. 210, Op. 13, D. 7. 6011.

9. Dokumenty o sluzhilykh lyudyakh, glavnym obrazom - zhiltsakh (o naznacheniyakh, perevodakh, lgotakh, otpuskakh, otstavke, o «priezdakh» i smotrakh, o netchikakh, otpiske u nikh imeniy i zaklyuchenii v tyurmu, o pozhalovanii za sluzhby pomestnymi i denezhnymi okladami, o sprave pridach [Documents on Serving People, Mostly Tenants (Appointments, Transfers, Benefits, Leaves, Resignations, on "Visits" and Inspections, on Absentees, Confiscation of Their Estates and Imprisonment, on Awarding with Estates and Money for Their Service, on Making Allotments)]. Rossiyskiy gosudarstvennyy arkhiv drevnikh aktov [Russian State Archive of Ancient Acts], F. 210, Op. 9, D. 6, Part 2. 4301.

10. Veselovskiy S.B., ed. Dokumenty Pechatnogo prikaza (1613-1615 gg.) [Prikaz of the Seal Documents (1613-1615)]. Moscow, Nauka Publ., 1994. 479 p. 
11.Elassonskiy A. Memuary iz russkoy istorii [Memoirs from Russian History]. Khroniki Smutnogo vremeni [Chronicles of the Time of Troubles]. Moscow, Fond Sergeya Dubova Publ., 1998, pp. 163-210.

12. Zabelin I.E. Minin i Pozharskiy. Pryamye $i$ krivye v Smutnoe vremya [Minin and Pozharsky. The Honest and the Unscrupulous in the Time of Troubles]. Saint Petersburg, Russkaya simfoniya Publ., 2005. 272 p.

13. Zamyatin G.A. Iz istorii borby Shvetsii i Polshi za moskovskiy prestol v nachale XVII veka. Padenie kandidatury Karla Filippa i votsarenie Mikhaila Fedorovicha [From the History of the Struggle of Sweden and Poland for the Moscow Throne in the Early 17th Century. The Fall of Carl Philip's Candidacy and the Reign of Mikhail Fedorovich]. Zamyatin G.A. Rossiya i Shvetsiya v nachale XVII veka. Ocherki politicheskoy $i$ voennoy istorii [Russia and Sweden in the Early $17^{\text {th }}$ Century. Essays on Political and Military History]. Saint Petersburg, Evropeyskiy dom Publ., 2008. 494 p.

14. Zamyatin G.A. K istorii Zemskogo sobora 1613 goda [To the history of the Zemsky Sobor of 1613]. Trudy Voronezhskogo gosudarstvennogo universiteta [Works of Voronezh State University], 1926, vol. III, pp. 71-74.

15. Zimin A.A. Akty zemskogo sobora 1612$1613 \mathrm{gg}$. [Acts of the Zemsky Sobor of 1612-1613]. Zapiski Otdela rukopisey. Vyp. 19 [Manuscript Department Notes. Iss. 19]. Moscow, Gosudarstvennaya biblioteka SSSR im. V.I. Lenina, 1957, pp. 186-194.

16. Kozlyakov V.N. Smuta v Rossii. XVII vek [The Time of Troubles in Russia. $17^{\text {th }}$ Century]. Moscow, Omega Publ., 2007. 528 p.

17. Koretskiy V.I., Lukichev M.P., Stanislavskiy A.L. Dokumenty o natsionalno-osvoboditelnoy borbe v Rossii v 1612-1613 gg. [Documents on the National Liberation Struggle in Russia in 1612-1613]. Lukichev M.P. Boyarskie knigi XVII veka: Trudy po istorii $i$ istochnikovedeniyu [Boyar Books of the $17^{\text {th }}$ Century: Works on History and Source Studies]. Moscow, Drevlekhranilishche Publ., 2004, pp. 198-234.

18. Lyubomirov P.G. Ocherk istorii Nizhegorodskogo opolcheniya 1611-1612 gg. [Essay on the History of Nizhny Novgorod Militia of 16111612]. Podvig Nizhegorodskogo opolcheniya. T. 2 [The Deed of the Nizhny Novgorod Militia. Vol. 2]. Nizhniy Novgorod, Knigi Publ., 2011, pp. 11-452.

19. Morozova L.E. Rossiya na puti iz Smuty. Izbranie na tsarstvo Mikhaila Fedorovicha [Russia on Its Way Out of the Time of Troubles. Election of Mikhail Fedorovich to the Throne]. Moscow, Nauka Publ., 2005. 467 p.

20. Nizhegorodskaya uchenaya arkhivnaya komissiya. Deystviya Nizhegorodskoy gubernskoy uchenoy arkhivnoy komissii: sb. st., soobshcheniy, opisey del i dokumentov. T. XI. Pamyatniki istorii Nizhegorodskogo dvizheniya $v$ epokhu Smuty $i$ zemskogo opolcheniya 1611-1612 gg. [Nizhny Novgorod Scientific Archive Commission. Actions of Nizhny Novgorod Provincial Scientific Archive Commission. Collection of Articles, Reports, Inventories of Cases and Documents. Vol. XI. Monuments of History of the Nizhny Novgorod Movement in the Time of Troubles and Zemskoe Militia of 1611-1612]. Nizhny Novgorod, Tipo-litografiya aktsionernogo obshchestva "Samoobrazovanie", 1912. XXXIII + 570 p.

21. Veselovskiy S.B., ed. Novye akty Smutnogo vremeni. Akty podmoskovnykh opolcheniy i Zemskogo sobora 1611-1613 gg. [New Acts of the Time of Troubles. Acts of the National Militia near Moscow and the Zemsky Sobor of 1611-1613 gg.]. Chteniya $v$ Imperatorskom obshchestve istorii $i$ drevnostey rossiyskikh pri Moskovskom universitete. Kn. 4 [Readings in the Imperial Society of Russian History and Antiquities at Moscow University. Book 4]. Moscow, Sinodalnaya tipografiya, 1911. XIV + 228 p.

22. Novyy letopisets [A New Chronographer]. Polnoe sobranie russkikh letopisey. T. XIV, ch. 1 [Full Collection of Russian Chronicles. Vol. XIV, part 1]. Saint Petersburg, Tipografiya M.A. Aleksandrova, 1910, pp. 23-154.

23. Piskarevskiy letopisets [Piskarevskiy Chronographer]. Polnoe sobranie russkikh letopisey. T. 34 [Full Collection of Russian Chronicles. Vol. 34]. Moscow, Nauka Publ., 1978, pp. 31-220.

24. Platonov S.F. Moskovskoe pravitelstvo pri pervykh Romanovykh. [The Government of Muscovy under the First Romanovs]. Platonov S.F. Sobranie sochineniy: v 6 t. T. 3 [Collection of Essays. In 6 vols. Vol. 3]. Moscow, Nauka Publ., 2012, pp. 254-302.

25. Morozov B.N., Stanislavskiy A. L. Povest o Zemskom sobore 1613 goda [The Story of the Zemsky Sobor of 1613]. Voprosy istorii, 1985, no 5, pp. 90-94.

26. Priezd i otpusk iz Moskvy datskogo poslannika Ivervinta, perevodchika Muchki i dvoryanina Martyna Golfenda s pozdravleniem tsarya Mikhaila Feodorovicha o vstuplenii ego na rossiyskiy prestol i s predlozheniem ob okonchanii sporov izdavna mezhdu oboimi gosudarstvami proiskhodivshikh kasatelno Laplandii [Arrival and Departure from Moscow of Danish Ambassador Everwent, Interpreter Muchka and Nobleman Martyn Golfand with Congratulations to Tsar Mikhail Feodorovich on his Accession to the Russian Throne and with a Proposal to End the Longstanding Dispute Between the Two States on Lapland]. Rossiyskiy gosudarstvennyy arkhiv drevnikh aktov [Russian State Archive of Ancient Acts], F. 53, Op. 1, D. 1. (1614 g.). 3421.

27. Buganov V.I., Kuzmina L.F., eds. Razryadnaya kniga 1598-1638 gg. [Charge Book of 
1598-1638]. Moscow, Institut istorii SSSR AN SSSR Publ., 1974. 398 p.

28. Skazanie Avraamiya Palitsyna [The Narrative of Abraham Palitsyn]. Moscow, Leningrad, Izd-vo AN SSSR, 1955.348 p.

29. Sobranie gosudarstvennykh gramot $i$ dogovorov, khranyashchikhsya $v$ Gosudarstvennoy kollegii inostrannyyh del. Ch. II [Collection of State Certificates and Agreements Stored in the State Board of Foreign Affairs. Part II]. Moscow, Tipografiya Selivanovskogo, 1819. $3+$ VIII $+19+612 \mathrm{p}$.

30. Sobranie gosudarstvennykh gramot $i$ dogovorov, khranyashchikhsya $v$ Gosudarstvennoy kollegii inostrannykh del. Ch. III [Collection of State Certificates and Agreements Stored in the State Board of Foreign Affairs. Part III]. Moscow, Tipografiya Selivanovskogo, 1822. XII $+540 \mathrm{p}$.

31. Sukhotin, L.M. Pervye mesyatsy tsarstvovaniya Mikhaila Fedorovicha (Stolbtsy Pechatnogo prikaza) [The First Months of the Reign of Mikhail Fedorovich. (Prikaz of the Seal Columns)].
Moscow, Sinodalnaya tipografiya, 1915. XXIV + $240 \mathrm{p}$.

32. Cherepnin L.V. Zemskie sobory Russkogo gosudarstva XVI-XVII vv. [Zemsky Sobors of the Russian State of the $\left.16^{\text {th }}-17^{\text {th }} c.\right]$. Moscow, Nauka Publ., 1978. $418 \mathrm{p}$.

33. Uvarov P.B., Dmitrina S.G. Sovremennaya otechestvennaya istoriografiya ob istoricheskom znachenii izbraniya na tsarstvo Mikhaila Fedorovicha Romanova [Modern Russian Historiography on the Historical Significance of the Election to the Throne of Mikhail Fedorovich Romanov]. Vestnik YuzhnoUralskogo gosudarstvennogo universiteta. Seriya «Sotsialno-gumanitarnye nauki», 2018, vol. 18, no. 2, pp. 36-40.

34. Eskin Yu.M. Dokumenty o Mangazee v Smutnoe vremya [Documents on Mangazeya in the Time of Troubles]. Novye materialy po istorii Sibiri dosovetskogo perioda [New Materials on the History of Siberia in the Pre-Soviet Period]. Novosibirsk, Nauka Publ., Sibirskoe otdelenie, 1986, pp. 44-54.

\section{Information about the Author}

Dmitry V. Liseitsev, Doctor of Sciences (History), Leading Researcher, Institute of Russian History, RAS, Dm. Ulyanova St., 19, 117292 Moscow, Russian Federation, Liseitsev@mail.ru, https://orcid.org/0000-0002-8632-2152

\section{Информация об авторе}

Дмитрий Владимирович Лисейцев, доктор исторических наук, ведущий научный сотрудник, Институт российской истории РАН, ул. Дм. Ульянова, 19, 117292 г. Москва, Российская Федерация, Liseitsev@mail.ru, https://orcid.org/0000-0002-8632-2152 